\title{
Morphology Derived Flag
}

National Cancer Institute

\section{Source}

National Cancer Institute. Morphology Derived Flag. NCI Thesaurus. Code C117627.

An indication or description that morphology assessment data is a derived value. 